\title{
The Behaviour of Some Grapevine Varieties to the Guignardia bidwellii Fungus Attack
}

\author{
Liliana TOMOIAGA*, Veronica Sanda CHEDEA \\ Research Station for Viticulture and Oenology Blaj, România \\ *corresponding author: tomoiagaliliana@yahoo.com \\ BulletinUASVM Horticulture 77(1) / 2020 \\ Print ISSN 1843-5254, Electronic ISSN 1843-5394 \\ DOI:10.15835/buasvmcn-hort: 2019.0042
}

\begin{abstract}
Guignardia bidwellii or black rot of vine is one of the most dangerous diseases that occur in vineyards in the center of Transylvania. The objective of this work was the tolerance testing of varieties and clones homologated at SCDVV Blaj to the Guignardia bidwellii attack. The behavior of vine varieties to the Guignardia bidwellii fungus attack was characterized by the analysis of the severity of the symptoms according to a scale in function of the attack degree (AD). The results obtained revealed the tolerance of the tested varieties: 'Rubin' (AD=0.13\%), 'Amurg' $(\mathrm{AD}=0.25 \%)$, 'Brumariu' $(\mathrm{AD}=0.78 \%)$, 'Radames' $(\mathrm{AD}=0.96 \%)$ and 'Blasius' $(\mathrm{AD}=0.97 \%)$, a medium tolerance presented 'Selena' (AD=9.28\%) variety and 'Neuburger-10 Bl' (AD=5.04\%), 'Iordana 9-1 Bl' (AD=6.40\%), 'Riesling de Rhin 7-2' (AD=7.2\%), 'Sauvignon-9 Bl' (AD=9.28\%), 'Traminer roz-60 B' clones (AD=17.5\%) and susceptibility for 'Astra' variety $(\mathrm{AD}=25.56 \%)$ and 'Riesling italian-3 $\mathrm{Bl}$ ' $(\mathrm{AD}=22.4 \%)$, 'Pinot gris-34 $\mathrm{Bl}$ ' $(\mathrm{AD}=30.60 \%)$, 'Feteasca regala-21 Bl' $(\mathrm{AD}=31.50 \%)$, 'Muscat Ottonel-12Bl' (AD=35.30\%), 'Feteasca alba-29 $\mathrm{Bl}$ ' clones $(\mathrm{AD}=38.40 \%)$. The results obtained regarding the behavior of grapevine in the climatic conditions specific to the studied area for the 2016-2018 period, show that the lowest values of AD were registered for the 'Rubin' (AD=0.13\%), 'Amurg' $(\mathrm{AD}=0.25 \%)$, 'Brumariu' $(\mathrm{AD}=0.78 \%)$, 'Radames' $(\mathrm{AD}=0.96 \%)$ and 'Blasius' $(\mathrm{AD}=0.97 \%)$ varieties homologated at SCDVV Blaj.
\end{abstract}

Keywords: Attack degree, Black rot, tolerant varieties

\section{Introduction}

Guignardia bidwellii de (Ellis) Viala and Ravaz, the pathogen of the black rot of the vine, is at the present time one of the most important fungal pathogens of the vine world. Depending on climatic conditions, the reserve of the inoculation, and the sensitivity of the varieties, if the attack is not adequately controlled, the harvest losses associated with this disease may vary between 5 - 100\% (Janex-Favre et al., 1993, Tomoiaga et al., 2002). In the vineyards of Romania, by the year 2006, the infections of black rot were extremely rare and with minor economic importance. In recent years, amid climate change, the incidence and severity of the disease has continuously increased in particular in the vineyards of central Transylvania, causing major production losses, with direct implications on wine quality and viticulturists' income in this area (Tomoiaga and Comsa, 2010). Although at present time there are different methods and means of preventing and combating the attack of black rot, genetic endurance is the most rational and economical way to control this disease especially in plantations cultivated in the sustainable system (Alves et al., 2007; Wilcox, 2003). 
Table 1. Characterization of vine varieties from susceptibility/tolerance point of view to black-rot attack (Ries, 1999)

\begin{tabular}{ccc}
\hline Characterization & Code & Attack degree (AD) $\%$ \\
\hline Immune & I & 0 \\
\hline Tolerant & T & $0,1-5$ \\
\hline Middle tolerant & MT & $5,1-18$ \\
\hline Susceptible & S & $>18,1$ \\
\hline
\end{tabular}

Table 2. The duration of the shade of leaves and temperature, combinations necessary for the production of the black rot foliar infection.

\begin{tabular}{cccccccccc}
\hline Temperature $\left({ }^{\circ} \mathrm{C}\right)$ & 10 & 12 & 15 & 18 & 21 & 23 & 26 & 29 & 32 \\
\hline Minimum hours of leaves humectation & 24 & 12 & 9 & 8 & 7 & 7 & 6 & 9 & 12 \\
\hline
\end{tabular}

\section{Materials and methods}

Experiments were carried out during the 2016 - 2018 period in the Tarnave and Aiud vineyards. Research focused on testing the behavior of new varieties and clones homologated at SCDVV Blaj to the attack of Guignardia bidwellii fungus. There was a random network consisting of 18 experimental plots cultivated with varieties and clones approved at SCDVV Blaj: 'Astra', 'Amurg', 'Brumariu', 'Blasius,', 'Radames,' 'Rubin' and 'Selena' varieties and 'Feteasca alba-29 Bl','Fetească regala-21 Bl', 'Iordana 9-1 $\mathrm{Bl}$ ', 'Muscat Ottonel$12 \mathrm{Bl}$ ', 'Neuburger-10 Bl', 'Pinot gris-34 Bl', 'Riesling italian-3 Bl', 'Riesling de Rhin 7-2', 'Sauvignon-9 $\mathrm{Bl}$ ', 'Traminer roz-60 $\mathrm{Bl}$ ' clones, the evaluation having been done in the field conditions of natural infection.

The tolerance of vine varieties and clones homologated at SCDVV Blaj to the attack of Guignardia bidwellii fungus has been characterized by analysis of the severity of symptoms (expressed as attack degree - AD), based on observations of frequency and intensity of the attack. The determination of the susceptibility of vine varieties and clones to Guignardia bidwellii was made in June, July, August and September. The notation was carried out on varieties, examining a variable number of vine hubs, depending on the area of the plantation. The diagnosis was completed with microscopic symptoms of the pathogen. For classifying varieties from the point of view of susceptibility/tolerance to black-rot attack, a 4 class scale has been used, depending on the level of attack (Tab. 1) adapted from Ries (1999).

The cycle of the Guignardia bidwellii fungus development is heavily influenced by humidity and temperature (Tab. 2). The risk assessment of infection implies: determination of contamination periods, based on climate data, the duration of wetting the leaves, temperature, pluviometry and hygrometry. The risk of infection can be calculated based on the correlation between the length of the period of wetting the leaves required for the infection to occur and temperature variations (Tab. 2).

\section{Results and Discussions}

In Romania, the genetic enhancement of vines for obtaining disease-resistant varieties remains a primary objective in research programmes, as a solution for the vineyard culture in sustainable system with reduced number of plant health treatments.

From the analysis carried out in this study, the plantations were affected annually by the Guignardia bidwelli attack, but there were differentiations regarding $\mathrm{AD}$, in relation to the climatic conditions favourable to the evolution of the disease and the cultivated variety (Fig. 1). The first symptoms of the disease were manifested at the beginning of June, firstly on the leaves by the appearance of circular spots of brown - red color, with brown edges, with dimensions of $0.5-2$ $\mathrm{cm}$. On the upper side of the leaves, on the spots appear black, punctiform formations arranged in concentric circles, consisting of fungus' pycnidia and pycnospores.

The attack begins on the leaves at the base of the strings and extends to the ones at the top. On the shoots the stains that are formed are much elongated. The characteristic attack manifests on the berries, when they reach $2 / 3$ of the normal 


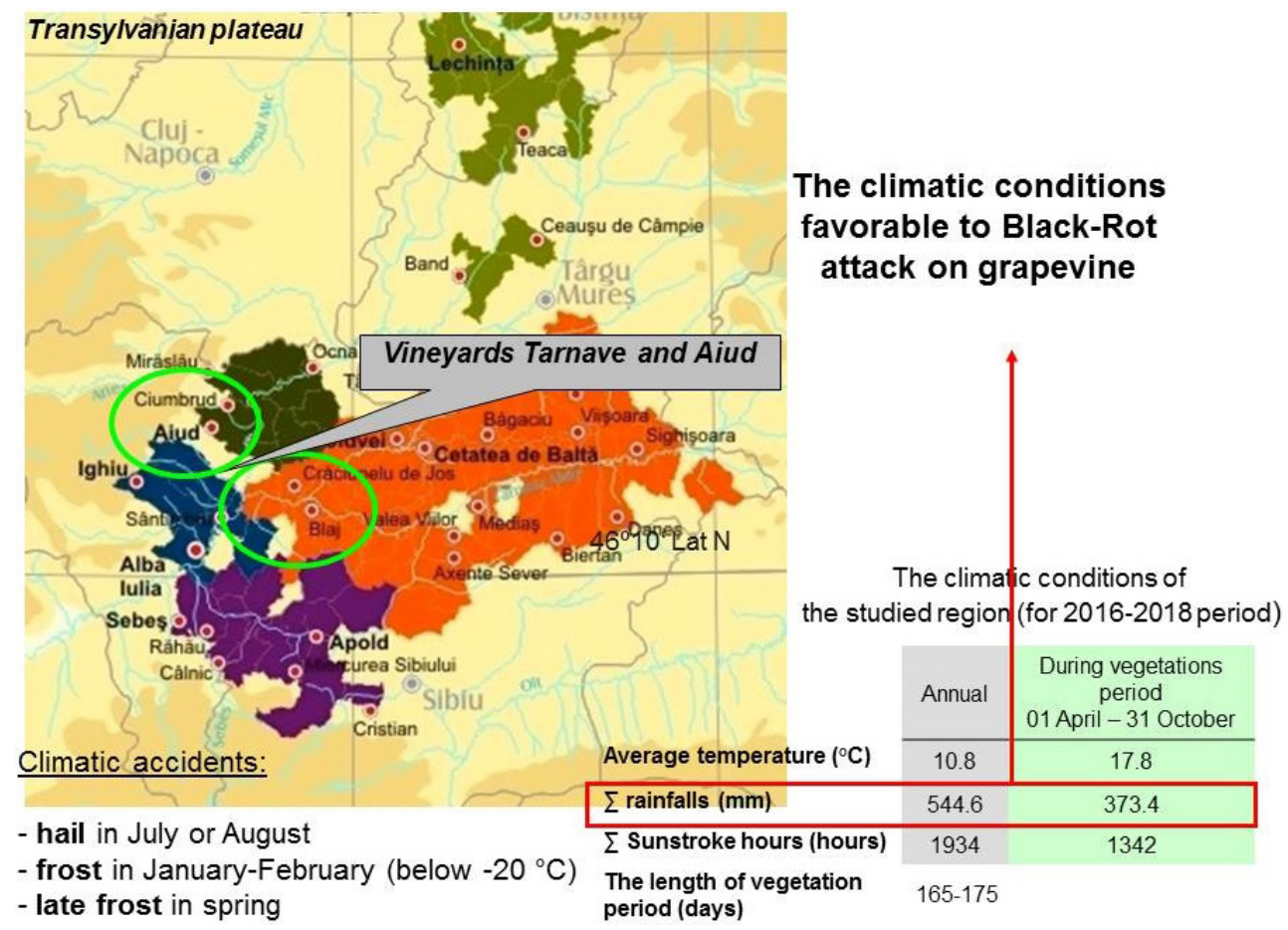

Figure 1. Climatic condition in Transylvania plateau vineyards favorable to the Guignardia bidwellii attack on grapevine

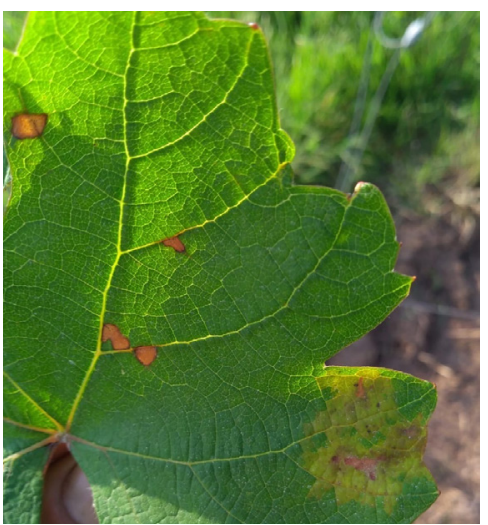

(A)

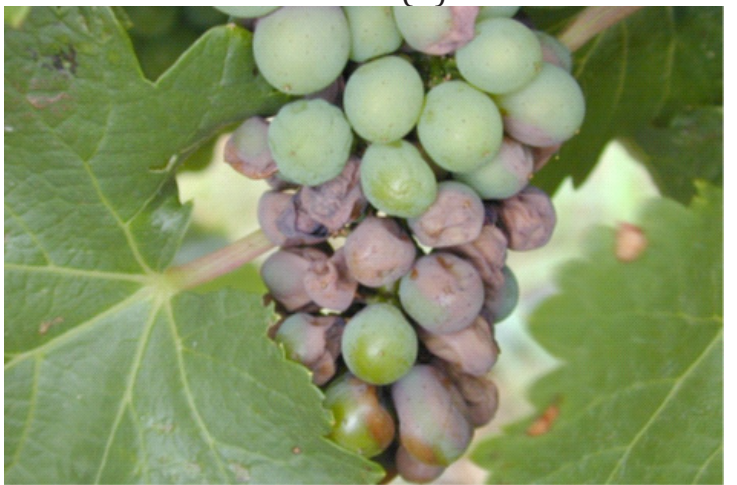

(C)

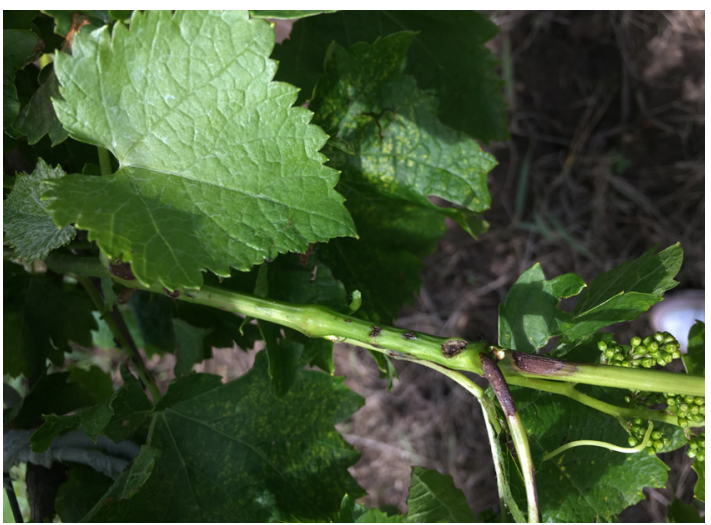

(B)

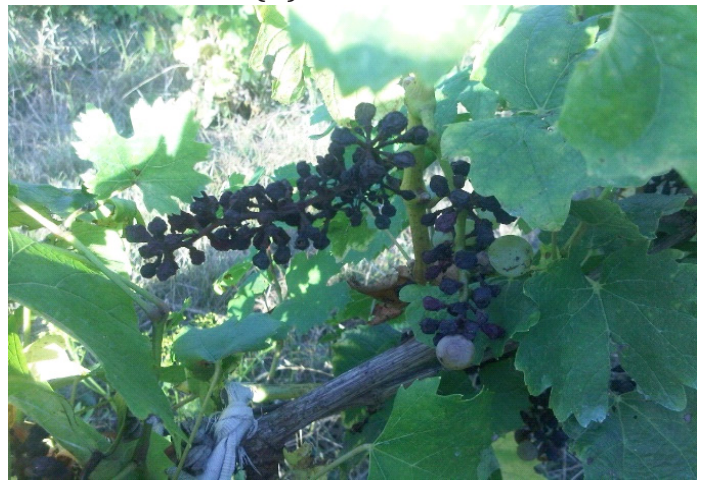

(D)

Figure 2. (A) Symptoms of Guignardia bidwellii on the leaves - first stage of the attack; (B) Lesions of Guignardia bidwellii on green stem - second stage of attack; (C) Bunch symptoms of Guignardia bidwellii - third stage of young berries attack; (D) "Mummied" grapes - last stage of the attack on the grapes 


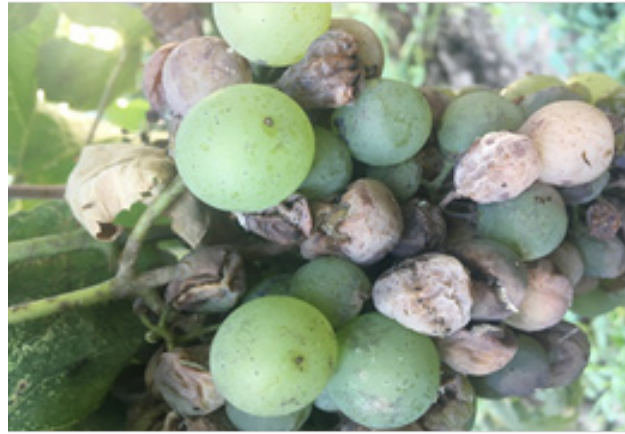

(A) Guignardia bidwellii on grape bunch

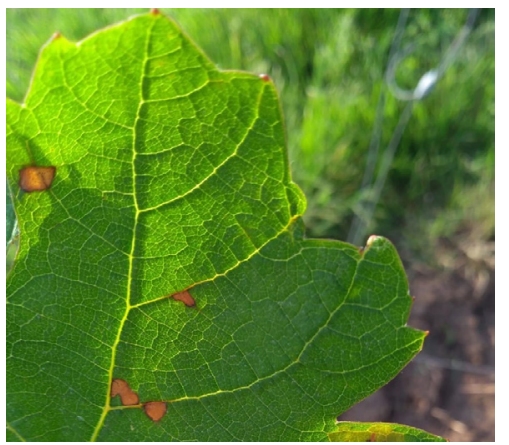

(C) Guignardia bidwellii leaf symptoms

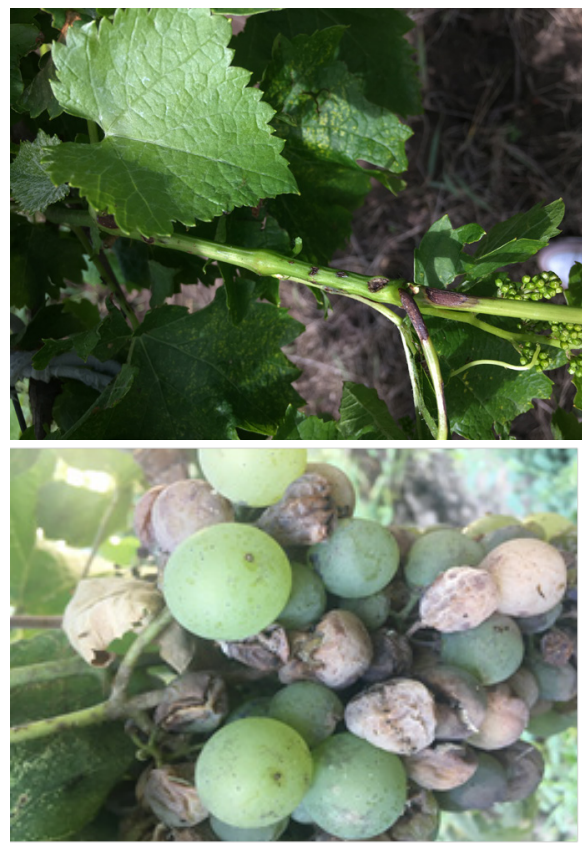

(E) Guignardia bidwellii symptoms on green stem (upper photo) and on bunch (lower photo)

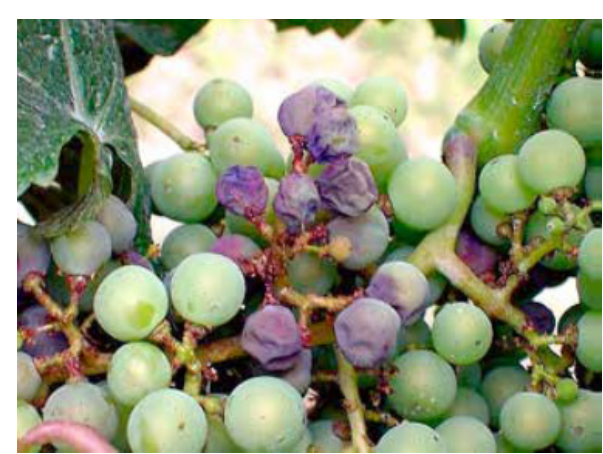

(B) Plasmopara viticola or grape downy mildew on grape bunch

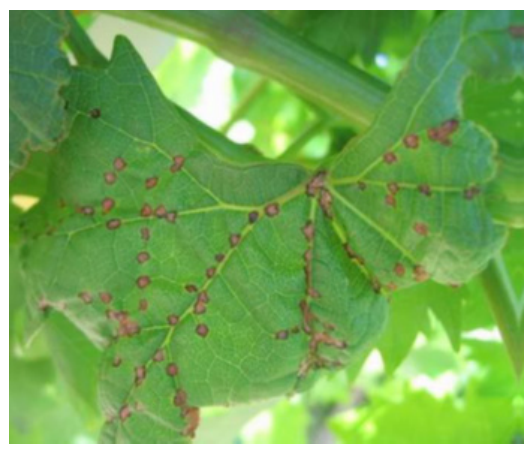

(D) Leaf symptoms of anthracnose Elsinoe ampelina (black spot)

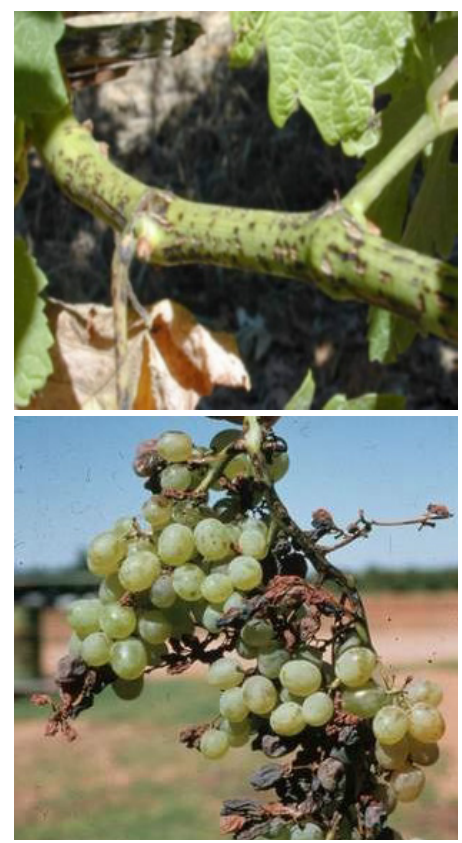

(F) Symptoms of Phomopsis viticola disease on green stem (upper photo) and Phomopsis rot of berries symptoms (lower photo)

Figure 3. Comparative images of Guignardia bidwellii attack symptoms and of Plasmopara viticola, Elsinoe ampelina and Phomopsis viticola attack 
Table 3. Tolerance/susceptibility of varieties and clones of vines homologated at SCDVV Blaj at the attack of Guignardia bidwellii fungus ( $\mathrm{F}=$ frequency of the attack, I=intensity of the attack, $\mathrm{AD}=$ attack degree)

\begin{tabular}{cccccc}
\hline Crt.no & Variety & F $\%$ & I $\%$ & AD $\%$ & $\begin{array}{c}\text { Variety } \\
\text { Characterization }\end{array}$ \\
\hline 1 & Rubin & 2.80 & 4.80 & 0.13 & T \\
\hline 2 & Amurg & 4.50 & 5.60 & 0.25 & T \\
\hline 3 & Brumariu & 8.50 & 9.20 & 0.78 & T \\
\hline 4 & Radames & 9.20 & 10.50 & 0.96 & T \\
\hline 5 & Blasius & 9.00 & 10.80 & 0.97 & T T \\
\hline 6 & Neuburger -10 Bl & 28.00 & 18.00 & 5.04 & MT \\
\hline 7 & Iordana 9-1 Bl & 32.00 & 20.00 & 6.40 & MT \\
\hline 8 & Riesling de Rhin 7-2 & 40.00 & 18.00 & 7.20 & MT \\
\hline 9 & Selena & 40.00 & 18.00 & 7.20 & MT \\
\hline 10 & Sauvignon-9 Bl & 29.00 & 32.00 & 9.28 & S \\
\hline 11 & Traminer roz- 60 Bl & 70.00 & 25.00 & 17.50 & S \\
\hline 13 & Rieslig italian 3- Bl & 80.00 & 28.00 & 22.40 & S \\
\hline 14 & Astra & 80.00 & 32.00 & 25.56 & S \\
\hline 15 & Feteasca regala -21 Bl & 85.00 & 36.00 & 30.60 & S \\
\hline 16 & Muscat Ottonel-12 Bl & 90.00 & 37.00 & 35.30 & \\
\hline 17 & Feteasca alba -29 Bl & 90.00 & 43.00 & 38.40 & \\
\hline
\end{tabular}

size. On the attacked berries appear brown spots, with reddish hue in colored grapes. In favorable conditions the disease develops explosive, the attack quickly propagates from one berry to another. The attacked berries have a dehydrated appearance. In dry time, the berries attacked are blacken and mummified, in rainy periods the berries are rotting completly (Fig. 2).

The attack of black rot can be confused with the attack of grapevine downy mildew, anthracnose, Phomopsis cane and leaf blight (Fig. 3 ). The presence of black punctiform pycnidia confirms the presence of black-rot attack.

From the analysis of the assessment results of the susceptibility/tolerance of varieties homologated at SCDVV Blaj at the attack of blackrot taking into account the average values of $\mathrm{AD}$ revealed the tolerance of 'Rubin' ( $A D=0.13 \%$ ), 'Amurg' ( $\mathrm{AD}=0.25 \%)$, 'Brumariu' $(\mathrm{AD}=0.78 \%)$, 'Radames' (AD $=0.96 \%)$ and 'Blasius' (AD = $0.97 \%)$ varieties. 'Astra' variety $(\mathrm{AD}=25.56 \%)$ manifested a very high sensitivity to the attack of Guignardia bidwellii fungus. The same behavior was reported for the clones: 'Riesling Italian $-3 \mathrm{Bl}$ ' $(\mathrm{AD}=22.40 \%)$, 'Pinot Gris-34 Bl' $(\mathrm{AD}=30.06 \%)$, 'Fetească regala-21 Bl' (AD $=31.05 \%)$, 'Muscat Ottonel-12Bl' (AD = 35.30\%), 'Fetească alba-29 $\mathrm{Bl}^{\prime}(\mathrm{AD}=38.40 \%)$. 'Selena' variety $(\mathrm{AD}=9.29 \%)$ and the clones 'Neuburger-10 Bl' $(\mathrm{AD}=5.04 \%)$,
'Iordana 9-1 Bl' (AD = 6.40\%), 'Riesling de Rhin 7-2', (AD = 7.20\%), 'Sauvignon-9 Bl' (AD = 9,28\%), 'Traminer roz-60 Bl' (AD = 17.50\%), showed an average tolerance to the attack of the Guignardia bidwellii fungus (Tab. 3).

In all three years of study, a correlation was observed between high rainfall, above $10 \mathrm{~mm}$, high temperatures above $15^{\circ} \mathrm{C}$ and infection pressure, respectively, frequency and intensity of Guignardia bidwellii attack. Thus, in June and July 2016-2018, a few weeks with daily intense precipitation combined with high temperatures caused the frequency of attack to increase to average values between $85-90 \%$ on the 'Feteasca regala $21 \mathrm{Bl}^{\prime}(\mathrm{F}=90 \%)$, 'Feteasca alba $29 \mathrm{Bl}$ ' ( $\mathrm{F}$ = 90\%), 'Muscat Ottonel $12 \mathrm{Bl}^{\prime}(\mathrm{F}=90 \%)$ and 'Pinot gris $34 \mathrm{Bl}$ ' $(\mathrm{F}=85 \%$ ) clones (Tab. 3). For the same climatic conditions, the frequency of the attack recorded the lowest values, below $5 \%$, on the 'Rubin' ( $F=2.80 \%)$ and 'Amurg' ( $F=4.50 \%)$ varieties (Tab. 3). The intensity of the black-rot attack was particularly high for the 'Feteasca alba 29Bl' ( $\mathrm{F}=37 \%$ ) and 'Muscat Ottonel 12Bl' ( $F=43 \%$ ) clones, whereas the intensity of the attack was much lower on the 'Rubin' and 'Amurg' varieties with an average intensity of $4.80 \%$ and $5.60 \%$ respectively (Tab. 3 ). 


\section{Conclusions}

The black-rot of the vine is one of the most dangerous diseases that manifest in the plantations of the vineyards of central Transylvania. Taking into account the average values of the attack degree during the 2016 - 2018 experimental period, the results obtained on the behaviour of vine varieties in the climatic conditions specific to the studied area denote that the lowest values of the attack degree was recorded in 'Rubin' ( $\mathrm{AD}=0.13 \%)$, 'Amurg' ( $\mathrm{AD}=0.25 \%)$, 'Brumariu' ( $\mathrm{AD}=0.78 \%)$, 'Radames' (AD=0.96\%) and 'Blasius' $(\mathrm{AD}=0.97 \%)$ varieties while the highest values were recorded in 'Astra' variety ( $\mathrm{AD}=25.56 \%)$ and 'Riesling italian-3 Bl' $(\mathrm{AD}=22.4 \%)$, 'Pinot gris-34 $\mathrm{Bl}$ ' $(\mathrm{AD}=30.60 \%)$, 'Feteasca regala-21 $\mathrm{Bl}^{\prime}(\mathrm{AD}=31.50 \%)$, 'Muscat Ottonel-12Bl' (AD=35.30\%) and 'Feteasca alba-29 $\mathrm{Bl}^{\prime}$ clones $(\mathrm{AD}=38.40 \%)$.

\section{References}

1. 1. Janex-Favre MC, Parguey-Leduc A, Jailloux F (1993). The Ontogeny of Pycnidia of Guignardia bidwellii in culture. MyCol. Res. 97: 1333-1339.

2. 2. Tomoiaga L, Criveanu H and Micle S (2002). Monitoring of climatic parameters an effective solution of fighting against the black rot of the vine (Black-Rot), UTC-N Symposium „Modern Science and Energy”, 337-341.

3. 3. Tomoiaga L and Comsa M (2010). The strategy of optimization for combat the Black Rot of vine (Guignardia bidwellii), in the ecoclimatic conditions from vineyard Tarnave. Bulletin of University of Agricultural Sciences and Veterinary Medicine Cluj-Napoca, Horticulture 67(1): 500.

4. 4. Alves A, Phillips, AJL, Henriques I, Correia A (2007). Rapid differentiation of species of Botryosphaeriaceae by PCR fingerprinting. Research in Microbiology, 158: 112121.

5. 5. Wilcox WF (2003). Black rot Guignardia bidwellii (Ellis) Viala and Ravaz. Disease Identification Sheet No. 102GFSG-D4. Cornell Cooperative.

6. 6. Ries SM (1999). Black Rot of Grape. Reports on Plant Diseases. RPD No. 703. 